\title{
PERAN MEDIA MASSA DALAM PEMBINAAN KERUKUNAN HIDUP MAS YARAKAT DIKABUPATEN MAMUJU
}

Oleh: Muhammad As'ad

\begin{abstract}
Abstrak
This research was conducted in Mamuju, West Sulawesi. Focus study is Radar Sulbar Newspaper and Radio Suara Manakarra. This research aims to describe the role of mass media in socializing and constructing pluralism and multiculturalism. This use qualitative method where data was collected by interview and article searching, and then analyzed by descriptive analysis.

This research indicates that the role of mass media in socializing and constructing pluralism and multiculturalism is quite well. Process of socialization take place substantively. The program and rubric of these mass media more for Islam people, as resident of majority, but it isn't discriminative action.
\end{abstract}

Keywords: mass media, pluralism, multiculturalism, construction, socialization.

\section{PENDAHULUAN}

$\mathrm{M}$

asyarakat Indonesia adalah masyarakat yang majemuk \{plural istic society) baik secara vertikal yang dicirikan oleh adanya sekat sosial, ekonomi dan politik maupun secara horizontal yang ditandai olah realitas keberadaan satuan-satuan sosial berdasarkan budaya, kelompok etnik, agama, dan bahasa. Kemajemukan tersebut yang merupakan kekayaan sosial kultural dilengkapi fakta fisik sebagai negara kepulauan terbesar di dunia. 
Muhammad As 'ad

negara dalam mengelola perbedaan entitas, agama, bahasa dan tradisi. Rezim Orde Baru yang cenderung otoritas represif dengan obsesi stabilitas dan keamanan nasional hanya berhasil meredam konflik tetapi tidak menyelesaikannya. Pemaknaan Bhineka Tunggal Ika semata diorientasikan pada pengarusutamaan (mainstreaming) Tunggal Ika dan menafikan Bhineka yang menjamin hak hidup dan koeksistensi berbagai kelompok dengan ciri khas masing-masing. Otoritarianisme politik pada era Orde Baru yang ditopang oleh ideologi pembangunan (developmentalism) yang artifisial mengedepankan pertumbuhan dan mengabaikan pemerataan sambil memarjinalkan kearifan lokal (local wisdoms). Strategi politik demikian ini tidak berhasil merajuk keharmonisan hidup dalam masyarakat.

Sulit dipungkiri bahwa media massa mempunyai kekuatan dan pengaruh yang signifikan terhadap pilihan dan sikap politik masyarakat. Bahkan dalam proses demokratisasi, eksistensi media masa acapkali diasumsikan sebagai pilar keempat kekuatan demokrasi terutama media audio visual yang secara imperatif sangat berpengaruh terhadap pikiran dengan perhatian publik serta jangkauan yang luas karena mampu membuka akses ke pelosok desa.

Walaupun demikian, tidak lepas juga dari sorotan bahwa media pers sangat sarat nilai dan kepentingan dan acapkali dituding sebagai alat provokasi dengan sengaja melakukan blow up opini di akar rumput (grass root). Makanya, media massa kadangkadang malah mengakibatkan publik menjadi frustrasi, termasuk tampilan berita dalam bingkai ideologis tertentu yang memperlebar ruang lahirny a paradoks.

Berdasarkan latar belakang penelitian di atas, Balai Litbang Agama Makassar merasa memiliki tanggung jawab moral dan intelektual untuk mengadakan penelitian evaluatif tentang peran media dalam pembinaan kerukunan hidup masyarakat, termasuk sosialisasi wawasan multikultural. Masalah penelitian ini dirumuskan sebagai berikut: bagaimana perkembangan media massa lokal di Kabupaten Mamuju? dan peran apakan yang dimainkan oleh media massa dalam pembinaan kerukunan hidup masyarakat ?

Sehubungan dengan masalah yang telah dikemukakan, makapenelitian ini bertujuan untuk:

Mengidentifikasi keberadaan berbagai jenis dan bentuk media massa lokal di Kabupaten Mamuju. 
Mendeskripsikan peran media massa dalam pembinaan kerukunan hidup masyarakat;

Hasil penelitian ini diharapkan berguna bagi Departemen Agama besertajajarannya serta Pemerintah Daerah sebagai input dalam penyusunan program dan kebijakan pembinaan kerukunan masyarakat di Kota Mamuju. Juga sebagai bahan informasi bagi segenap pihak yang mempunyai perhatian terhadap perkembangan media massa atau yang peduli terhadap pembinaan kerukunan masyarakat.

\section{KAJIAN PUSTAKA}

\section{A. Media Massa}

Pada pasal 6 Undang-Undang Pers dicantumkan beberapa peranan media pers, yakni: a) memenuhi hak masyarakat untuk mengetahui; (b) menegakkan nilai-nilai dasar demokrasi, mendorong terwujudnya supremasi hukum dan hak asasi manusia, serta menghormati kebhinekaan; (c) mengembangkan pendapat umum berdasarkan informasi yang tepat, akurat dan benar; (d) melakukan pengawasan, kritik, terhadap hal-hal yang berkaitan dengan kepentingan umum; dan (e) memperjuangkan keadilan dan kebenaran.

Dalam kajian mengenai jurnalistik, terdapat beberapa fungsi dan peran yang inheren (melekat) pada media pers, sebagian yang dirumuskan beberapa ilmuan diantaranya Horald D. Laswell yaitu:

1. Penjagaan atau pengawasan lingkungan (surveillance of the environment).

2. Menghubungkan bagian-bagian yang terpisah dari masyarakat untuk menanggapi lingkungannya (correlation of the part of society in responding to the environment).

3. Meneruskan warisan sosial dari generasi ke generasi berikutnya (transmission of the social heritage).

Robert K. Merton, mengemukakan fungsi pers, antara lain: penganugerahan status (status conferral) dan pengukuhan akhlak atau etika (ethicizing), kemudian dielaborasi oleh John Vivian (1991) yang menemukan empat fungsi yang niscaya pada media komunikasi massa, terdiri atas: (1) Memberikan informasi (providing infor- 
Muhammad As'ad

motion); (2) menyuguhkan hiburan (providing entertainment); (3) meyakinkan (helping to persuade); dan (4) mendorong ke arah kohesi sosial (contributing to social cohesion).

Mengenai pengaruh dan efek media massa, Jahi (1988) mengutip pendapat Carter, bah wa minimal terdapat tiga efek y ang dimunculkan media komunikasi massa: kognitif, afektif, dan konatif. Meski ketiga dimensi tersebutberhubungan satu dengan lainnya, tetapi sifatnya independen.

Berkaitan dengan media massa, dikenal berbagai teori seperti The Bullet Theory of Communication yang diperkenalkan Wilbur Schramm. Teori ini masih dominan sebagai model komunikasi massa yang populer di Indonesia dengan sebutan "teori peluru" atau "teori jarum suntik". Media massa dipostulatkan sebagai sangat perkasa dengan efek yang langsung, dan segera pada publik. Komunikator menggunakan media massa untuk menembaki khalayak dengan pesan-pesan persuasif bahkan imperatif yang tidak mampu mereka bendung.

\section{b. Multikulturalisme}

AzyumardiAzra (2005) memaknai teori multikultural sebagai titiktolakdari "politics of recognition", pengakuan terhadap keragaman kultural, tradisi, agama dan sebagainya. Senada dengan preposisi sebelumnya, Charles Taylor dalam Multiculturalism: Examining the politics of recognition (1994) sebagaimana dikutip oleh Muh. Ali menyatakan: masing-masing kelompok budaya dan agama menuntut dan berhak mendapatkan pengakuan dan penghargaan.

Kalangan ilmuwan sosial mengistilahkan multikulturalisme dengan cultural pluralism dengan asumsi bahwa multikulturalisme menghendaki terbangunnyatatananan kehidupan (life-order) yang seimbang, harmonis, dan fungsional. Orang-orang yang berwawasan multikultural adalah mereka yang telah menghayati dan mengimplementasikan kebudayaan secara tepat, efektif, akurat, serta ideal dalam interaksi dan komunikasi dengan orang lain.

Dengan mengacu pada persfektif historis, multikulturalisme adalah sejarah masyarakat majemuk, meliputi Amerika Serikat dan Kanada yang selama beberapa dasawarsa punya kepedulian untuk mengkonstruksi teori-teori dan proposisi 
multikulturalisme, dalam rangka menemukan pakem yang tepat untuk membingkai warga bangsanya yang didominasi kaum imigran yang datang dari berbagai penjuru dunia dengan budaya mereka masing-masing.

Target strategis idiologi multikulturalisme adalah meretas hak-hak kolektif manusia (huququl basyariah) terutama yang minoritas dan mengkonstruksi kesadaran untuk kerjasama dalam wujud koeksistensi dan mengalami keanekaragaman politik dan budaya dalam kesetaraan (co-experienced differences in equality) demi maslahat al-ammah (kemaslahatan bersama). Kebijakan awal multikulturalisme, paling tidak terpeliharanya oase keragaman budaya (cultural variety) dari gilasan universalisasi-globalisasi-budaya. Disusul kemudian terbangunnya hibriditas budaya dari berbagai varian budaya yang melampaui kekakuan identitas komunal yang narsistik (bangga terhadap milik sendiri) sebagai yang otentik dan superior yang kadang melahirkan sekat-sekat primordialisme.

\section{c. Kerukunan hidup Masyarakat.}

Kerukunan memeiliki fungsi penting bagi kehidupan masyarakat. Kerukunan bia berfungsi sebagai savety valve bagi disintegrasi social. Kerukunan dapat mereduksi konflik, di samping secara fungsional-struktural, kerukunan itu membangun keseimbangan social (social equilibrium). Pada tataran komunikasional, kondisi rukun (kerukunan) yang mempersyaratkan adanya interaksi resiprokal, hubungan karib, keintiman,-kedamaian, ketenangan yang didasarkan pada sikap keterbukaan, kerjasama, sentuhan kasih, dan saling pengertian, pada gilirannya dapat membangun dan memperkuat integrasi social. Kerukunan pada dimensi ini berfungsi sebagai conflict reduction dan juga safety valve terjadinya disintegrasi sosial (Yusuf. 2003).

Kerukunan hidup beragama merupakan dambaan umat manusia. Sebagian besar umta manusia yang menganut Islam, Kristen, Yahudi (Judaism), dan agama-agama lainnya, ingin hidup rukun, damai, dan tenteram. Seperti kita ketahui, Islam Kristen, dan Yahudi adalah agama-agama Nabi Ibrahim (Abrahamic religions) yang mengajarkan hidup rukun. Namun, ketiga agama samawi ini dapat disebut sebagai siblings, kakak-adik, yang di samping kesamaan-kesamaan dan kemiripan-kemiripan mereka, juga menampilkan perbedaan-perbedaan yang kadang menimbulkan konflik antara umat agama tersebut. Dan, sebagaimana 1 azimnya kakak dan adik, ketiga agama 


\section{Muhammad As'ad}

ini sering pula terlibat dalam kecemburuan satu sama lain dan bahkan persaingan (sibling rivalry), khususnya antara Kristiani dan Islam yang sama-sama memiliki klaim sebagai agama universal dan penyelamat (savior) bagi seluruh anak manusia. Karena itu agama Kristen dan Islam melintasi batas-batas kesukuan, etaisitas, wilayah geografis, dan cultural, yang pada gilirannya menimbulkan balapan dalam mendapatkan sebanyak mungkin penganut-penhanut baru (Azra. 2003).

Setiap pemeluk agama meyakini bahwa agama yang dianutnya adalah jalan yang paling benar. Keyakinan tersebutpada satu sisi menimbulkan spiri dalam mempelajari dan mengamalkan ajaran agamanya karena dipercaya hanya dengan jalan yang diajarkan agamanya maka ia akan mencapai kebahagiaan dan keselamatan. Namun pada sisi lain, keyakinan tersebut dapat menimbulkan prasangka (prejudice) bahwa di luiar agama yang dipeluknya dianggap sesat. Dua sisi itulah yang sering kali menjadi penyebab timbulnya berbagai konflik atau ketidak rukunan dalam kehisupan antar maupun intern umat beragama (Tholkhah.2004).

\section{METODE PENELITIAN}

Penelitian ini bersifat deskreptif kualitatif. Dalam proses penjaringan data, teknik yang dipergunakan adalah wawancara mendalam (in-depth interview), observasi dan dokumentasi. Wawancara mendalam dilakukan dengan para informan, yaitu orang-orang yang dianggap banyak mengakses dan mengetahui masalah yang diteliti yang terdiri dari masyarakat umum, wartawan, pimpinan redaksi, akademis, pemerhati media massa, dan praktis media elektronik. Pemilihan informan yang menjadi target wawancara di samping ditentukan secara purposif, j uga dilakukan secara snowballing - melalui informasi yang diberikan oleh informan yang sudah diwawancarai sebelumnya.

Observasi dilakukan untuk melihat kondisi geografis dan demografis setting penelitian, mengamati secara langsung fenomena sosial dalam realitas kehidupan masyarakat baik peristiwa maupun perilaku multikultural yang dapat dijaring. Di samping itu, observasi juga dimaksudkan untuk mencocokkan hasil wawancara dengan realitas kultural sejauh yang dapat dilihat, yang mungkin tidak terungkap melalui wawancara. Untuk melengkapi data yang dijaring melalui wawancara dan pengamatan (observation), dilakukan pengumpulan data tertulis berupa dokumen dan lektur lainnya. 


\section{IV . HASIL DAN PEMBAHASAN}

\section{A. Gambaran Umum Media Massa Di Sulawesi Barat}

Kabupaten Mamuju memiliki posisi sangat strategis dibanding kabupaten lainnya di Sulawesi Barat setelah ditetapkan sebagai ibukota Propinsi Sulawesi Barat karena merupakan pusat administrasi pemerintahan. Media massa sebagai sarana komunikasi dan informasi sekaligus sebagai sarana pendidikan masyarakat akan memanfaatkan posisi strategis ini dalam rangka pengembangan dan peningkatan peranannya dalam pembinaan dan pelayanan masyarakat di Sulawesi Barat.

Sebelum Propinsi Sulawesi Barat mengembangkan diri menjadi propinsi tersendiri dan masih bernaung di bawah kordinasi Propinsi Sulawesi Selatan, Kabupaten Mamuju secara geografis relatif $j$ auh dari pusat pemerintahan propinsi. Ditetapkanny a Kabupaten Mamuju (Kota Mamuju) sebagai ibukota Propinsi Sulawesi Barat, memacu gerak dinamikaperkembangannya. Perubahan-perubahan sangat signifikan, baik infra struktur maupun demografis, termasuk di dalamnya komunikasi massa. Media elektronik audio (radio) dan audio-visual (TV), baik yang dipancarkan dari Jakarta maupun dari Makssar sudah lama menjangkau daerah ini.

Pada saat penelitian ini (2007), siaran-siaran televisi yang menjangkau Kabupaten Mamuju sudah cukup banyak. Semua siaran televisi berskala nasional sudah menjangkau daerah ini, sehingga pemirsa dapat memilih secarabebas siaran-siaran yang diinginkannya. Bahkan siaran-siaran luar negeri pun menjangkau daerah ini bagi orang yang memiliki peralatan penangkap siaran yang mamadai.

Perkembangan media audio-visual ini, sebagaimana pada daerah-daerah lainnya, menggeser peran media audio (radio) yang sebelumnya dominan di tengah masyarakat. Meskipun demikian, peranan yang dimainkan oleh media radio masih tetap dibutuhkan masyarakat. Di antara masyarakat masih terlayani oleh media massa ini, baik yang berskop nasional maupun lokal.

Pemancar-pemancar radio lokal yang umumnya berupa FM masih cukup banyak jumlahnya di Kabupaten Mamuju ini. Antara lain yang dapat dikemukakan, ialah: 1 . Glamor FM, 2. Denis FM, 3. Larian Indah AM, 4. GopsillaFM, 5. MaidamaFM, 6. Radio BanuaMalabbi (RBM), dan 7. Radio Suara Manakkara (RSM). 
Muhammad As'ad

Selain RBM dan ASM, semuanya dikolola oleh pihak swasta sehingga merupakan suatu prestasi tersendiri bagi masyarakat Mamuju. Radio Banua Malabbi (RBM) umurnya masih sangat muda seiring dengan mudanya usia Propinsi Sulawesi Barat karena dibina oleh Pemda Propinsi Sulawesi Barat dalam hal ini Infokom. Adapun radio Suara Manakkara (RSM), sudah lama mengabdikan dirinya dalam masyarakat Kabupaten Mamuju dan keberadaan akan diuraikan lebih lanjut.

Media massa cetak sudah menjangkau Kabupaten Mamuju sejak waktu yang lama dengan segala keterbatasannya. Kendala utama yang menyebabkan keterbatasan ini berkaitan dengan sarana komunikasi dan transportasi yang menghubungkan daerah ini dengan daerah-daerah luarnya, sebagaimana telah digambarkan.

Surat kabar sebagai media cetak yang banyak digemari oleh masyarakat sudah menjangkau daerah ini. Kompas sebagai surat kabar harian yang berskala nasional menjangkau daerah ini, terutama setelah adanya cetakan di Kota Makassar. Harianharian yang berpusat di Makassar peredarannya menjangkau daerah ini, meskipun dengan eksemplar terbatas. Harian "Fajar" yang berpusat di Makassar cukup diminati oleh masyarakat di daerah ini. Demikian pulaharian 'Tribun" dan "Pedoman Rakyat". Hanya saja yang disebutkan terakhir peredarannya di daerah ini tersendat-sendat.

Surat kabar yang besifat lokal di Kabupaten Mamuju ini masih sangat terbatas. Saat penelitian ini hanya terdapat dua buah surat kabar, satu bersifat harian, yaitu "Radar Sulbar" dan lainnya terbitan berskala (3 kali sebulan), yaitu " Mamuju Pos". Hanya saja yang disebutkan terakhir ini juga penerbitannya tersendat-senadat.

Kendala utama peredaran surat kabar di Kabupaten Mamuju sampai saat ini adalah sarana transportasi. Semua surat kabar yang telah disebutkan dicetak di Makassar dan untuk sampai di Mamuju melalui transportasi darat yang memerlukan waktu sekita 10 jam. Radar Sulbar yang "naik cetak" pada awal malam, paling cepat sampai di Mamuju pada pagi hari. Untuk sampai di tangan langganan rata-rata sekitar pukul 09,00 atau waktu-waktu kesibukan kerja. Adapun harian-harian yang "naik cetak" pada dini hari (Kompas, Fajar, dan Tribun) rata-rata sampai di Mamuju atau di tangan pembacapada sore atau petang hari. Keterlambatan-keterlambatan ini lebih dialami parapembaca pada kecamatan-kecamatan di luar kota Mamuju, yang diantaranya masih berjarak seratusan $\mathrm{km}$. 


\section{B. Profil Radar Sulbar.}

Surat kabar ini adalah satu-satunya harian yang dimiliki oleh Propinsi Sulawesi barat sampai saat ini. Hal ini merupakan prestasi tersendiri yang dicapai oleh putraputra terbaik daearah ini. Surat kabar ini termasuk dalam Fajar grup yang merupakan sal ah elemen dari Jawa Post.

Penampilan harian Radar Sulbar cukup menarik, tidak berbeda dengan harianharian lainnya, seperti Fajar dan Tribun. Hanya saja karena pertimbangan tertentu, harian ini tidak terbit pada hari-hari libur dan setiap penerbitan hanya 16 halaman. Berkaitan dengan itu, kontribusi yang ditanggung pelanggan atau pembacarelatif murah, yaitu: langganan Rp 40.000,- / bulan dan harga eceran Rp 1.800,- yang dibulatkan pengecer menjadi Rp 2.000,- Harga langganan ini mengalami kenaikan menjadi Rp 45.000,-/bulan mulai tanggal 01 Mei 2007.

Secara singkat penampilan Radar Sulbar digambarkan sebagai berikut: Sebagimana pada harian-harian lainnya, halaman pertama yang merupakan halaman utama memuat berita-berita utama menurut penilain redaksi, halaman 2 dan 3 merupakan halaman khusus Mamuju (Kota Mamuju); halaman 4 dan 5 halaman khusus Sulawesi Barat (Radar Mandar), halaman 6 ruang Opini, halaman 7 halaman aneka berita ditambah sambungan berita halaman utama (Aneka), halaman 8 berita bergambar (Radar Society) atau Kreasi Remaja, halaman 9 berita Olahraga Sepak Bola, halaman 10 berita berbagai olahraga (Allsport), halaman 11 berbagai berita nasional (Nasional), halaman 11 berita tentang pendidikan dan HAM, halaman 13 tentang Ekonomi dan Bisnis, halaman 14 tentang berbagai informasi kemajuan teknologi (Infotek), halaman 15 tentang Kesehatan dan Keluarga, dan halaman 16 tentang berita atau informasi selebriti (infotainment).

Untuk lebih jelas penampilan tersebut dikemukakan contoh pada terbitan tanggal 2 April 2007, topik berita yang ditampilkan pada halaman pertama adalah: APBD Sulbar Disertai Catatan; Pasien Diare Banjiri RSUD Mamuju; Posisi Warga ATM Tidak Jelas, Ikut Pilkada Polewali Mandar atau Mamasa; Komisi IV DPR Kunjungi Sulawesi Barat; Perayaan Maulid 1428 H di Salabose: Tradisi Tiri Pising Terkikis. Pada halaman utama ini diberi variasi dengan pemuatan kolom "Ikandi" dengan penampilan selebriti Neneng Nuraeni; iklan khusus Radar Sulbar: Anda Ingin Mengetahui Sulawesi Barat Lebih Banyak? Silahkan Berlangganan Radar Sulbar, 
Muhammad As'ad

Hanya Rp. 40.000 / Bulan, yang diiringi dengan pencantuman alamat-alamat di Mamuju, Majene, Polewali, dan Wonomulyo yang dapat dihubungi jika ingin pasang iklan atau tidak terima Koran; iklan Telkomsel; ajakan dukungan kepada Nudrin peserta KDI4 berasal dari Sulbar; SMS Pembaca; dan Pojok: - APBD Sulbar Disertai Catatan Berarti Masih Perlu Penyempurnaan.

\section{Profil Radio Suara Manakarra}

Radio Suara Manakarra (RSM) adalah radio suara Pemerintah Kabupaten Mamuju. RSM didirikan dan diresmikan pengoperasiannya oleh Bupati Mamuju Almalik Pababari pada tanggal 31 Mei 2003. Radio ini memakai frekuensi AM 864,0 Khz, FM 99,1 Mhz. dengan kekuatan pemancar 750 watt. Wilayah layanan siaran adalah Kabupaten Mamuju dan sekitarnya. Untuk menjangkau wilayah layanan itu dibangun menara setinggi $30 \mathrm{~m}$. dari permukaan laut. Lokasi penyiaran dalam lingkan Infokom Kabupaten Mamuju, jalan Ahmad Kirang no. 39 Mamuju.

Radio ini merupakan media penyiaran publik yang berfungsi sebagai media informasi, hiburan, pendidikan, dan pengembangan usahabagi masyarakat. Slogan radio yang dipilih adalah:"Radio Suara Manakkara media informasi \& komunikasi hadir bersama membangun Mamuju".

Dalam melaksanakan fungsi-fungsi tersebut, RSM menetapkan visi, yaitu "mewujudkan masyarakat sadar informasi, yang cerdas, kritis, dan produktif'. Dari visi ini dapat dipahami bahwa sebagai media informasi, RSM berusaha menciptakan masyarakat Kabupaten Mamuju sebagai masayarakat yang sadar informasi, yang menjadikan informasi itu sebagai suatu kebutuhan hidup. Sebagai media pendidikan, RSM berupaya mencerdaskan masyarakat dengan menyuguhkan informasi dan siaran yang mendidik masyarakat dalam berbagai aspek kehidupan. Sebagai media pengembangan usaha masyarakat, RSM berusaha meningkatkan perekonomian masyarakat dengan memacu produktifitas merekamelalui berbagai program siaran.

RSM telah melakukan peran dan fungsi sebagai media penyebarluasan informasi, membangun dan mengerahkan opini publik, memberikan hiburan, pendidikan dan pengetahuan kepada masyarakat serta mendorong pengembangan dunia usaha melalui paket iklan dan info layanan masyarakat. 
Dalam jadwal acara siaran yang ada di radio ini tidak terlihat program berita sebagai informasi berharga bagi para pendengar. Penyiaran berita-berita aktual dijadwalkan sebanyak 3 kali sehari lewat program Lintas Peristiwayang dilakukan pada pukul 12.00,16.00, dan 20.00. Dengan memperhatikan jadwal siaran tersebut, terlihat perubahan siaran untuk hari Sabtu dan Ahad sebagai hari libur kerja, terjadi padapagi hari, yaitu pukul $07.00 \mathrm{~s} / \mathrm{d} 14.00$. Dalamjadwal tersebut terlihat pula bahwa jadwal penyiar tidak mengalami perubahan.

\section{Pembinaan Kerukunan Hidup Masyarakat oleh Media Massa}

Salah satu upaya untuk membina dan memelihara kerukunan hidup masyarakat yang dilakukan oleh media massa adalah menanamkan wawasan multikultural dalam masyarakat. Multikulturalisme, secara terminologi, masih banyak masyarakat yang belum memahaminya secara jelas. Namun demikian, tidak berarti masyarakat sama sekali tidak memahami wawasan itu. Berbagai nilai-nilai budaya baik berupa tradisi maupun ajaran agama dipelihara oleh masyarakat Mamuju yang masuk dalam lingkup terminologi multilkulturalisme itu.

Sehubungan dengan itu sosialisasi wawasan multikulturalisme melalui media massa cetak (Radar Sulbar) dan media massa elektronik (Radio Suara Manakkara) tidak secara tersurat baik segi etimologi maupun terminologi, tetapi secara subsantif yang tercermin dalam fenomena masyarakat, baik menyangkut hal-hal yang harus dipelihara dan diperhatikan maupun hal-hal yang harus dihindari.

\section{Radar Sulbar}

Sebagai Koran umum, Radar Sulbar menjunjung tinggi nilai-nilai Pancasilayang di dalamnya terkadung nilai saling menghormati satu sama lain. Tujuan utama semua kegiatan dan akti vitas dari segi tinjauan politiknya untuk kemaslahatan umat manusia. Karena itu, Kehadiran media ini dengan suatu keyakinan harus memberikan kontribusi pada masyarakat, yang pada akhirnya demi kemaslahatan manusia.

Keragaman masyarakat sebagai suatu realitas, hampir terjadi di mana-mana. Keragaman itu berpotensi menimbulkan konflik, bahkan sudah menjadi realitas di berbagai daerah terjadinya konflik karena perbedaan etnis (suku) atau agama. Karena itu dalam etikajurnalistik, dilarang sama sekali untuk mempersoalkan SARA. Berkaitan 
Muhammad As'ad

dengan itu, Radar Sulbar memberikan ruang yang sama kepada semua umat beragama, termasuk di dalamnyanilai-nilai kebudayaan. Radar Sulbar berusaha mengakomodir semua kepentingan-kepentingan itu.

Radar Sulbar selalu mendukung kegiatan-kegiatan keagamaan, merespon program-program Pemerintah, selalu ikut berpartisipasi dalam menciptakan kedamaian, berupaya sesuai kemampuan sebagai pers untuk selalu mewujudkan kedamaian itu dalam hidup berbangsa dan bernegara.

Keterbukaan yang diberikan untuk semua pihak dibatasi oleh etika-etika yang mendukung misi kedamaian itu. Halaman "opini" diperuntukkan dan dimanfaatkan semua pihak untuk menyampaikan ide, gagasan dan pandangan; tetapi dengan syarat opini yang mau ditampilkan itu bukan opini yang menyinggung SARA, seperti opini yang mendeskreditkan agama lain, termasuk aliran kepercayaan.

\section{Radio Suara Manakarra}

Apabila diperhatikan program acara RSM yang telah dikemukakan, terlihat sebanyak 19 program acara, 10 di antaranya adlah program lagu-lagu hiburan. Program informasi (berita) dikemas dalam "Dinamika Manakarra". Berita atau informasi yang disampaikan dalam program ini adalah hasil liputan RSM sendiri, berita antara, dan het line media cetak. Program relay dari RRI tidak ada lagi. Selain program ini, khusus Sabtu terdapat program "Manakarra Sepekan" berisi siaran linitas berita sepekan yang berisi berita-berita penting dalam sepekan itu. Selain itu, terdapat acara "Lintas Peristiwa" setiap hari pada pukul 12.00,16.00, dan 20.00.

Dalam melakukan peliputan, petimbangan yang dipakai adalah missi RSM tanpa diskriminasi. Peristiwa atau acara yang diliput tergantung relevansinya dengan kepentingan masyarakat dan terjangkauanya oleh peliput. Dengan demikian informasi sebelum peliputan tentu diperlukan. Peristiwa dan acara yang dinilai penting adalah masalah pembangunan, termasuk di dalamnya masalah politik. Masalah keagamaan menjadi perhatian, tanpa membedakan agama. Hanya saja frekuensinya tergantung peristiwa dan acara itu. Sebagai contoh, pada tahun 2006 RSM telah mengadakan peliputan sebanyak 85 kali. Masalah keagamaan yang menjadi perhatian antara lain: Pemerintah Mamuju galakkan Yasinan, kehadiran Ustazah Lutfiah Sungkar di Mamuju, Pemda anggarkan bantuan Imam Masjid, Peringatan mauled Nabi oleh BKMT, 
Kegiatan Sulbar Berzikir, Musabaqah Tilawatil Qur'an, penerbitan tafsir berbahasa Mandar, khitanan missal oleh PD Muhammadiah, tarawih bersama, safari Ramadhan, buka puasa dengan anak yatim, peringatan Nuzul Qur'an, Idul Fitri, Idul Adha, anjangsan ke Panti Asuhan, Penyaluran bantuan ke Panti Asuhan, pelaksanan Jum' at Bersih, aksi solidaritas umatberagama Sulbar terhadap agresi Israel, perbaikan jalan pekuburan Nasrani, Perayaan Natal di Kalumpang-Bonehau, perayaan Natal di ATM

Setiap hari, RSM menetapkan suatu prodaram "Diambang Senja" yang berisi mata acara: pembacaan Ayat Suci Al Qur'an, Azan, dan Ceramah Agama (Islam). Untuk kelancaran program ini, RSM bekerjasama dengan Kanwil Dep.Agama Sulawesi Barat.

\section{KESIMPULAN DAN SARAN}

\section{A. Kesimpulan}

1. Penduduk Kab.Mamuju sudah tersentuh oleh berbagai media massa, baik cetak maupun elektronik seperti daerah-daerah lainnya. Hanya saja media cetak masih terbatas, antara lain dikarenakan oleh faktor geografis. Media cetak dan elektronik lokal sudah berkiprah meskipun juga dengan segala keterbatsannya.

2. Pembinaan kerukunan hidup masyarakar oleh media massa di Kapupaten Mamuju antara lain dengan menanamkan wawasan multikultural. Proses sosialisasi wawasan multikultural melalui media massa di Kab.Mamuju berlangsung secara substantif dengan pelayanan yang tidak diskrminatif. Frekuensi pelayanan di bidang keagamaan yang lebih banyak bagi umat Islam, sebagai penduduk mayoritas, bukan sebagai tindakan diskriminatif

3. Tingkat efektivitas pesan media massa lokal dalam sosialisasi wawasan multikultural belum terungkap dalam penelitian ini karena berbagai kendala. Respons masyarakat terhadap media elektronik audio-visual mengatasi respons media lainnya.

\section{B. Saran - Saran}

1. Kondisi kerukunan hidup masyarakat Mamuju yang kondusif senantiasa harus dipelihara bahkan ditingkatkan oleh semua pihak. Partiasipasi media massa sangat 
Muhammad As'ad

dibutuhkan dalam memelihara kondisi yang kondusif ini dengan berita dan siaran yang mendukung persatuan dan kesatuan.

2. Prinsip bebas bertanggung jawab betul-betul harus dipelihara oleh media massa agar misi pembangunan dapat berjalan dengan baik. Dan jati diri sebagai media umum juga terpelihara dengan memelihara pelayanan yang tidak diskriminatif.

\section{DAFTAR PUSTAKA}

Ahmad, H.abd.Kadir (ed.). 2006. Sistem Perkawinan di Sulawesi Selatan dan Sulawesi Barat. Makassar: INDOBIS Publishing.

Ali, Muhammad. 2003. Teologi Pluralis Multikultural. Menghargai Kemajemukan, Menjalin Kebersamaan, Cet. I. Jakarta: Kompa Media.

Al-Munawwar, Said Aqil. 2003. Departemen Agama dan Pengembangan Wawasan Multikultural Harmoni. Jurnal Multikultural dan Multireligius. Vol. II, No.5.

Amal, Taufiq Adnan (et.all). 2004. Politik Syariat Islam, dari Indonesia hingga Nigeria. Cet. I. Jakarta: Pustaka Alfabet.

Amri, Amin. 1981. Tanya Jawab Dasar-Dasar Penerangan. Edisi I. Bandung: Amrico.

Azra, Azyumardi. 2003. Merajuk Kerukunan Hidup Beragama antara Cita dan Fakta. Dalam Harmoni. Volume II No. 7. akarta: Puslitbang Kehidupan Beragama Badan Litbang Agama dan Diklat Keagamaan. 
2005. Kehidupan Beragama di Amerika: Pluralism, Sekularism, dan Multikulturalsm. Jurnal Pendidikan dan Kajian Keagamaan, Edisi I. Tahun ke-3.

Budhisantoso (1980). Televisi dan Masyarakat Pedesaan. Prisma. No. 3. tahun IX. Jakarta: LP3ES.

Budianta, Melani. 2003. Multikulturalisme dan PendidikanMultikultural, Sebuah Gambaran Umum, dalamTsaqafal, Vol. 1 No. 2.

Burhan Bungin, Burhan. 2003. Analisis Data Penelitian Kualitatif, Cet. I, Jakarta: RajaGrafindo.

Dawlay, M.Zaibuddin. (2003). Pengembangan Wawasan Multikultural antara Pemuka Agama Pusat dan Daerah, Harmoni. Balitbang Agama. Vol. II, No. 5.

Hamid, Ibnu. 2004. Konstruksi Realitas Politik dalam Media Massa; Sebuah Studi Critical Discourse Analysis Terhadap Berita-Berita Politik, Cet. I. Jakarta : Granit.

Jali, Amri. 1993. Komunikasi Massa dan Pembangunan Pedesaan di NegaraNegara Dunia Ketiga. Cet. III. Jakarta: Gramedia Pustaka Utama.

Nuruddin. 2005. Sistem Komunikasi Indonesia. Cet. II. Jakarta: Raja Grafindo Persada.

Pelras, Christian. 2006. Manusia Bugis. Cetakan Pertama. Jakarta: Nalar bekerjasam dengan Forum Jakarta-Paris, EFEO.

Poloma, Margaret. 2003. Contemporary Sociological Theory. Diterjemahkan oleh Tim Penerjemah Yasogama: Sosiologi Kontemporer, Cet. V. Yogyakarta: Raja Grafinka. 


\section{Muhammad As'ad}

Rahman, Darmawan Mas'ud. 1988. Puang dan Daeng Kajian Sistem Nilai Budaya Orang Balanipa Mandar. Disertasi. Makassar: Fakultas Pasca SarjanaUniversitas Hasanuddin.

Rohmin Dahuri, et.al. 2004. Pengelolaan Sumber Daya Wilayah Pesisirdan Lautan secara Terpadu. Cet. 3. Jakarta: Praduy Paramitha.

Thahir, H.Ince Abd.Rahman. 2006. Selayang Pandang Sejarah Adat Kabupaten Mamuju. Penerbit Mato Comp.

Tholkhah, Imam. 2004. Membangun Kualitas Kerukunan Umat Beragama. Dalam Harmoni. Volume III No. 12. Jakarta: Puslitbang Kehidupan Beragama Badan Litbang Agama dan Diklat Kegamaan.

Yusuf, Choirul Fuad. 2003. Pengembangan Wadah Kerukunan dan Ketahanan Masyarakat Lokal di Balikpapan. dalam Harmoni. Volume II No. 6. Jakarta: Puslitbang Kehidupan Beragama Badan Lirtbang Agama dan Diklat Keagamaan.

\section{Multikultural: Tantangan Transformasi Pendidikan} Nasional. dalam Edukasi Vol. IV No. 1 Januari. 